\title{
Technology for Energy Efficient Building Materials: Towards Sustainable Housing Delivery in Nigeria
}

\author{
Olufunmilola Adetayo Obakin* \\ Faculty of Environmental Design and Management, \\ Department of Architecture, University of Ibadan, Nigeria
}

\begin{abstract}
This research is intended to provide information on the need to replace high-energy building materials and practices with energy-efficient materials and technology for sustainable housing development. This paper presents a material produced from corn cob ash and kenaf fiber proposed as an energy-efficient building material. Little or no energy was utilized in its production and utilization. The paper presents a discussion on locally available and sustainable raw building materials, such as corn cob, coir, palm kernel shells, bamboo, and their ashes. The material used was locally obtained; they are corn cob, kenaf fiber, ordinary Portland cement, quarry dust, and potable water. The corn cob ash was obtained by air drying corn cob and burning it in a furnace at $650^{\circ} \mathrm{C}$ to produce carbon-free ash. The equipment used was also locally fabricated. Pictures showing the application of these materials and equipment are also showcased. Findings of this stuyd could be used to reduce the total amount of energy used in the provision of building services and products.
\end{abstract}

Keywords: Energy efficient, sustainable housing, corn cob ash, kenaf fibre, low cost building material

Received: 13 June 2018; Accepted: 2 August 2018; Published: 20 October 2018

\section{INTRODUCTION}

\section{A. Energy Efficient Building Materials}

The goal of energy efficient building materials is to reduce considerably the total amount of energy used in the provision of building services and products, this phenomenon is also known as energy efficiency or efficient energy use [1]. Reduction in energy consumption reduces costs of energy resulting in a financial cost saving to consumers if the energy saving offsets any additional costs of implementing an energy efficient technology or material. Reducing energy consumption is also a means of reducing greenhouse gas emissions. According to the International Energy Agency, improved energy efficiency in buildings, industrial processes and transportation could reduce the world's energy needs in 2050 by one third, and help control global emission of greenhouse gases.

Innovating to reduce the environmental footprint of developments, reduces the impact of development (industrial) activities by reducing the effect of carbon gases on the environment, for instance, the production of Portland cement generates emission of Carbon dioxide $\left(\mathrm{CO}_{2}\right)$. Various activities of human beings since the industrial revolution (around 1750) have increased the atmospheric concentration of carbon dioxide $\left(\mathrm{CO}_{2}\right)$ by $40 \%$, that is, from $280 \mathrm{ppm}$ in 1750 to $406 \mathrm{ppm}$ in early 2017 [2].

Energy efficiency therefore means providing the same level of energy with less amount of energy. It is hence, one way of reducing greenhouse emissions by human beings. For example, an insulated house uses less energy for heating and cooling its interior to attain a satisfactory temperature. The use of fluorescent lights or skylights in buildings, instead of incandescent lights, to attain the same level of illumination is another example. A more efficient technology or process is thereby primarily used to achieve energy efficiency. Energy efficient industrial processes, buildings, and all forms of transportation could reduce by one third the worlds energy needs in 2050 , and help control the global emission of harmful gases such as

\footnotetext{
${ }^{*}$ Correspondence concerning this article should be addressed to Olufunmilola Adetayo OBAKIN, Faculty of Environmental Design and Management, Department of Architecture, University of Ibadan, Nigeria. E-mail: morenifunmi@yahoo.com

(c) 2018 The Author(s). Published by KKG Publications. This is an Open Access article distributed under a Creative Commons AttributionNonCommercial-NoDerivatives 4.0 International License.
} 
carbon dioxide [3]. To address global warming, homes, vehicles and businesses must be made more energy efficient. Making them so is seen as a largely untapped solution to energy security, global warming, fossil fuel depletion and deforestation [3]. When a material or technology lasts longer or works better than its traditional version, but uses the same amount of energy, then it is more energy efficient. Or if it uses less energy to deliver the same performance as the traditional version, then it is more energy efficient. Ultimately, energy efficiency means doing more with less, that is, squeezing as much useful power out of as little energy as possible and not letting any go to waste [4].

In the last few decades, energy consumption has grown incredibly fast. There is therefore need to be more energy efficient conscious because there is danger of using up the planet's natural resources, of polluting the air we breathe and of destroying vital habitats. In order to save wildlife habitats, safeguard the planet, and make sure there is energy left for future generations, energy efficiency is a way of managing and limiting this growth in energy consumption. Energy efficiency is also the conservative use of energy in producing and utilizing materials for construction. It is found in general that large power plants work more efficiently, so they tend to be built as near as possible to fuel sources, hence when building and construction materials are sought from the building's immediate environment, it is regarded as energy conscious building or development.

It has been discovered that it is cheaper and more efficient to transport finished good than raw materials because finished goods are usually smaller in quantity than their raw materials which also includes wastes, i.e. 20 tonnes of corn (raw materials) may only produce 1 tonne of starch (finished good). It is therefore more energy efficient to locate starch processing plants in the rural area where the raw material is gotten, by so doing a lot of fuel and cost of transportation would have reduced. The amount of Carbon monoxide (air pollution/ozone depletion) from fuel consumed by a vehicle during transportation and released into the atmosphere is thereby reduced and the environment protected [5].

The best way to achieve energy efficient building materials is by employing the use of locally available materials as against importing materials from far away countries. It has been found that natural fibres cement composites are produced in most developing countries and they require only a low degree of industrialization for processing. In comparison with the equivalent volume of weight of steel, the energy required for the production of such natural fibres is small and their cost per unit strength is low $[6,7]$. The use of natural fibres is not only energy efficient, it also leads to the conservation of world's scarce resources for example timber forest. It leads to energy saving, cost saving and it helps in the protection of our environment.

\section{B. Sustainable Housing Delivery}

Sustainable housing is a term that depicts environmentally conscious housing. Its aim is to curtail the negative environmental footprint of houses by increasing efficiency and leniency in the utilization of development space, materials and energy. It is derived from an energy and ecologically conscious attitude to the activities of the built environment.

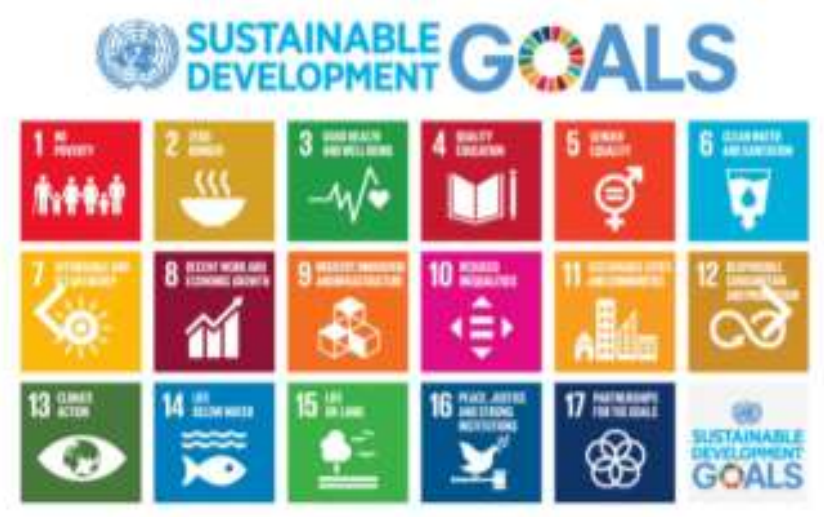

Fig. 1. United Nations sustainable development goals

A realistic approach to sustainable housing involves the use of low carbon materials and construction methods in housing delivery. Close attention must be paid to the sustainable methods and means of utilizing these materials for the good of all. This is paramount in enhancing welfare, wealth, productivity and health of occupants of buildings. It is cost effective and wastage and pollution are reduced [8]. World commission on Environment and Development [9], describes sustainable development as a development that meets the needs of the present generation without jeopardising the ability of the future generations to meet their own needs. In other words, a more sustainable design and development uses up less materials and energy during manufacture, use and disposal, so there would be more alternatives over for choices in the future. Sustainability therefore takes into account the entire product delivery course. The use of mechanical processes and mainly natural materials increases sustainability in the manufacturing stage and during disposal. The lightweight property of the products and reduced processes lowers energy and fuel consumption during transportation. Sustainable housing units will lead to Sustainable cities and communities which would enhance the fulfilment of goal 11 (SDG 11) of the United Na- 
tions Sustainable Development Goals (see figure 1). As part of sustainable development process, actions towards sustainable construction are required to create and use clean techniques and technologies for construction, and to utilize existing local resources so as to stimulate minimum negative impact to the environment. This implies: a) minimum use of non-renewable natural resources and promotion of substitutes; b) rationed use of renewable natural resources; c) minimum production of waste and pollutants that nature cannot recycle on its own; d) provision of appropriate spaces and quality of life required for human development [10, 11].

Currently most buildings in the world have a high content of reinforced concrete translating into high costs and has been a problem to the average citizen. Steel is partially scarce and its cost is ever increasing and even when available, its quantity and quality fall below the average demand of users in Nigeria. These inadequacies therefore led to the importation of steel from other producer countries. This factor has led to the abandonment of projects at various levels of construction, and housing deficit. In some cases storey buildings have had to be converted to bungalows or the number of storey of various buildings reduced to minimize cost to meet completion target. Hence the need for the development and use of locally available materials and technology to implement low cost housing. These locally available materials can be used with a small percentage of imported ones requiring simple technology.

Studies have been carried out on numerous plant fibres which are also energy efficient materials and they have been found to be alternatives in reinforcing concrete. It is expected that the use of these natural materials (plant fibres, quarry dust and pozzolans) in concrete will reduce the amount of steel, sand and cement that will be used hence, there will be energy reduction and reduced depletion of natural resources. For example, bamboo have been found to have a safe working strength of about $15 \mathrm{~N} / \mathrm{mm}^{2}$ in tension and also high tensile strengths which range from $260 \mathrm{~N} / \mathrm{mm}^{2}$ for intermodal sections and $160 \mathrm{~N} / \mathrm{mm}^{2}$ to $275 \mathrm{~N} / \mathrm{mm}^{2}$ at the nodal section respectively. These compete favourably with those of steel which are between $280 \mathrm{~N} / \mathrm{mm}^{2}$ and $500 \mathrm{~N} / \mathrm{mm}^{2}$.

This paper is therefore intended to provide information on the need to replace high energy building materials and practices with energy efficient materials and technology for sustainable housing development through review of literature, to present a report on the development of a suitable energy efficient building material named corn cob ash and kenaf fibre cement composites, and to experimentally determine the optimum ash and fibre content which would give reasonable workability and strength without requiring enormous energy consumption, and finally, to demonstrate the production of roofing tiles from the composite developed.

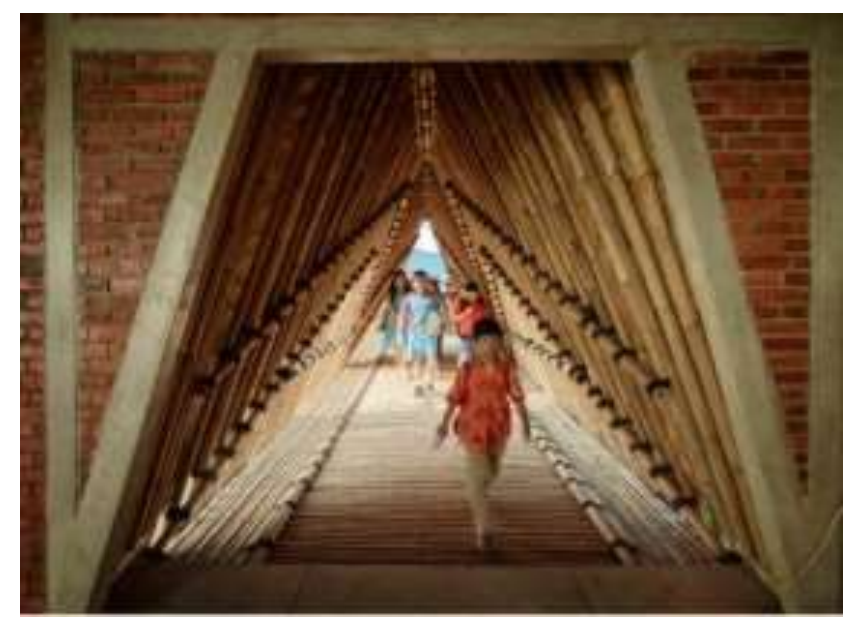

Fig. 2. School of Alfa Omega/RAW Architecture: Use of bamboo and bricks for sustainable buildings

Source: www.archdaily.com

\section{BENEFITS AND CHARACTERISTICS OF ENERGY EFFICIENT, LOW-COST, SUSTAINABLE BUILDING MATERIALS}

They are easy to manufacture (efficient manufacturing processes), faster and cheaper to construct. (See figure 2, the entire school was built using bamboo sought within $5 \mathrm{~km}$ of site to accelerate development while reducing carbon footprint, bricks, local craftsmen and was built within 4 months. They were able to save $30 \%$ initial budget by using low-cost materials with steel only when necessary. They are effective in waste utilization by recycling agroindustrial wastes, they are energy efficient and environment friendly and they help protect the environment. This is achieved by utilization of renewable resources in place of the fast depleting non-renewables. They aid poverty reduction through employment generation.

They aid Technology transfer and capacity building and procurement of technical knowhow and machines, creating capacities for productive employment and technology transfer and adoption at institutional and enterprise levels. They help in boosting energy saving technologies thus, making highly notable impact in lowering gaseous emissions, especially of carbon dioxide and in encouraging profitable competitiveness especially in the alternative materials sector [12]. They promote the 4 main goals of energy efficiency: 


\section{A. Reduce}

This involves reduction in cost and quantity of materials to be used, distances for transportation, this implies that locally available materials would be more energy efficient than imported materials.

B. Re-use

This indicates employing building materials or components for new applications with minimal alterations.

\section{Recycle}

This implies conversion of the previous material into some other form, usually by production of a lower grade product, since some degree of deterioration usually occurs during service so that re-use is not a possibility.

\section{Recover}

This is usually used to denote energy recovery from materials with limited recycling options. This needs careful consideration since energy recovery itself may have associated environmental problems like the energy cost in transporting waste over large distances.

\section{E. Dispose}

This should only be considered when all the above options have been excluded. There is need for greater public awareness of the situation and for the use of all materials to be seen in cyclic terms rather than the use and discard approach which is largely prevalent [5].

\section{LITERATURE REVIEW OF SOME ENERGY EFFICIENT MATERIALS AND TECHNOLOGY}

Some indigenous materials that have been investigated are discussed below:

\section{A. Sisal (Agave sisalane) Fibres}

This is the most extensively cultivated hard fibre in the world. It is a strong fibre. The plant has rigid bright green leaves about $10 \mathrm{~cm}$ wide and $150 \mathrm{~cm}$ long. Sisal has been successfully used as reinforcement in cement and concrete matrices.

\section{B. Plantain Fibres}

Plantain fibres are vegetable fibres traditionally used for making cords. They are cheap and abundantly available in Nigeria and are probably very suitable fibres for reinforcement purposes.

\section{Sugarcane (Saccharum officinarum) Fibres}

This is a waste material left over after the extraction of the juice of sugarcane known as bagasse. Sugarcane fibres have been used in the production of $1.2 \mathrm{~cm} 2$ panels, which are bonded with cement of up to $49 \%$ (12).

\section{Coconut (Coconut nucifera) Fibres}

A mature coconut has an outer covering made of fibrous material. This covering called the 'husk' consists of a hard skin and large coconut fibres embedded in a soft material. The fibres otherwise known as Coir can be extracted simply by soaking the husk in water to decompose the soft material surrounding the fibres. The fibres is light, elastic, exceedingly high in resistance to mechanical wear and dampness, and it is highly sound insulating especially in sea water [6].

\section{E. Jute Fibres}

Jute is grown mainly in India, China and Thailand solely for making ropes and bags to transport grains and other materials ranging from cement to sugar. It is strong in tension hence can also be used in the cement matrix.

\section{F. Flax Fibres}

Flax is a slender and erect plant grown mainly for its fibre. Both the tensile strength and modulus of elasticity of flax fibres are extremely high compared to those of other natural fibres.

\section{G. Bamboo}

Bamboo is a stemmed monocotyledonous perennial plant belonging to the tribe Bumbasea of the family Graminea. Bamboo can grow up to a height of $15 \mathrm{~m}$ with diameter within the range $25-100 \mathrm{~mm}$. It is grown naturally in the tropical and sub-tropical regions. Bamboo fibres are strong in tension and they can be used as reinforcing materials. Bamboo can also be fabricated to form a continuous reinforcing material. Bamboo can be used naturally as well but there is need for treatment before use.

\section{H. Earth/Clay/Mud/Laterite Construction}

Building with earth might be considered to be the best energy efficient construction, although, for restricted application, since both the origin and disposal site for the material may be immediately adjacent to the building. Prior to the industrial revolution earth was the most universally available bulk material for construction and its use was widespread. It was often mixed with some fibrous material such as straw to provide additional stability. In the nineteenth century there followed a rapid 
decline in its use in the developing world as bulk transport provided the means to move materials and fuels over large distances [5].

Earth building has the following attractions:

-the energy costs in production are extremely low

-earth product has high thermal mass, but better insulation properties than those of dense masonry, and provide temperature stability to the internal environment in both winter and summer, wet and dry conditions.

-good fire resistance and noise insulation are achieved -disposal at the end of service life is extremely simple

The main problems relating to the material are limited structural performance and susceptibility to the effects of weather or damp. The provision of a good roof with generous eaves projection is always advised. Where there is a possibility of wind driven rain, surfaces can be stabilized by application of calcium silicate solution or lime-based washes or coatings.

It is important that earth should be free of organic material since it is relatively unstable, traps moisture and provides a source of nutrition for living organisms that may move in. In some cases this may mean excavation of 1 metre or more of surface material in order to eliminate organic materials.

The following are the chief forms of earth construction technology:

Wattle and daub, cob, rammed earth construction, stabilized rammed earth construction, adobe (sun-dried mud bricks).

1) Wattle and daub: This form of construction is probably the most amenable to use with a minimum of skill and mechanized equipment. Typically, a simple timber shell for the building is produced and then panels of wattle are formed by weaving thin sapling twigs onto somewhat stouter sapling uprights. Weatherproofing is achieved by application of a mud or mud/straw mixture to the framework. For good results the walls should be clear from ground level. Protection can be achieved by application of lime render to the panels. Provided adequate protection is achieved, very long service life is obtainable, though such structures clearly have limited load bearing capacity and are at risk from impact damage.

2) Cob: Cob differs from the above technique in that walls can be built with little or no timber frame. To be suitable, soil must be cohesive, containing appreciable contents of clay, but with some other grittier material to improve dimensional stability. It is mixed with straw to a consistency suitable for compaction by threading underfoot. It is built freehand into the approximate required shape, lift by lift, perhaps rising up to $1 \mathrm{~m}$ at a time. Timber frames for openings can be built in by attaching broad, wedge shaped fillets of timber to uprights, which key into the cob. Lintels (of width equal to the overall wall width) can be made of substantial timber sections and similar sections can be used to form bearing for floor joists. Ceiling heights must allow for 2-3 percent shrinkage of the material on drying. When the earth has hardened, mainly by drying, the excess material is cut back to give the correct profile. Substantial thicknesses, typically of around $600 \mathrm{~mm}$, are required for the technique, weather protection again being by a lime based coating of some form.

3) Rammed earth construction: In rammed earth construction the cohesive qualities of a suitably graded earth based material are utilized without any form of fibre or other reinforcement. It is one of the most promising techniques for current use. In many cases earth can be used 'as dug' from the ground to produce satisfactory wall structures with a minimum of framing. A fairly dry earth mix of suitable composition and moisture is well compacted to form walls in lifts of about $600 \mathrm{~mm}$ between firmly held timber forms. The forms are initially braced by struts, which are removed as work progresses. Tensile forces on formwork are carried by ties which are removed at the end of each lift.

Use of Stabilisers in Rammed Earth Construction have the following benefits:

-They have increased compressive strength for improved load bearing capacity, including fixing to walls.

-They have increased weathering and damp resistance.

-They permit the use of otherwise unsuitable earth.

-They permit the use of material without any external finish.

Conversely, use of stabilizers increases costs, and makes disposal of the material more difficult once service life is finished.

Various stabilizers can be used according to availability. In the UK and even in Nigeria, cement is the most common but limes can also be used; non-hydraulic limes can be combined with pozzolan such as brick dust to ensure a reasonably prompt set, or hydraulic limes can be used if available. Optimum moisture contents must be evaluated at the desired cement content in order to ensure maximum compaction. High cement contents are not required. A proportion of 4 percent by weight of total materials is likely to double strength levels from around $2 \mathrm{~N} / \mathrm{mm}^{2}$ to $4 \mathrm{~N} / \mathrm{mm}^{2}$.

4) Adobe: This operates much along the same lines as rammed earth except that convenient size units (usually larger than standard clay bricks) are formed and allowed to dry in the sun. Clearly such techniques depend upon suitable drying conditions and are therefore more suited 
to hotter countries such as ours (Nigeria). However there may be value in using adobe bricks in conjunction with rammed earth to form certain details of structure such as gables (where compaction could be difficult) and openings or returns. Since the material is allowed to dry before use, the particle size requirement are less strict than for rammed earth through the same principles apply [5].

\section{Cellulose/Wood Fibre}

The wood panel industry uses glues and pressing techniques to turn otherwise unusable logs, branches, and various wood residues left over from sawing into thin, flat panels of wood. Such panels have a wide variety of uses from construction to toy making.

Plywood comprises of several layers of veneer bonded together with adhesives. The products of the cellulose panel industry are veneer, plywood, particleboard, and fiberboard [12].

\section{J. Agricultural Lignocellulosic Fiber}

Rice straw and waste tire particle composite boards were manufactured for use as insulation boards in construction, using the same method as that used in the woodbased panel industry [14]. The manufacturing parameters were: a specific gravity of 0.8 and a rice straw content (10/90, 20/80 and 30/70 by weight percentage of rice straw/waste tire particle). A commercial polyurethane adhesive for rubber was used as the composite binder. The water proof, water absorption and thickness swelling properties of the composite boards were better than those of wood particleboard. Furthermore, the flexibility and flexural properties of the composite boards were superior to those of other wood-based panel products. The composite boards also demonstrated good acoustical insulation, electrical insulation, anti-caustic and anti-rot properties. These boards can be used to prevent impact damage, are easily modifiable and are inexpensive. They are able to be used as a substitute for insulation boards and other flexural materials in construction [15].

\section{KENAF FIBRE, CORN COB ASH AND CEMENT COMPOSITE TESTING AND ROOF TILES PRODUCTION METHOD}

This section showcased the raw materials, production process, locally fabricated and low energy equipment used, and the finished product (Figures 3-11).

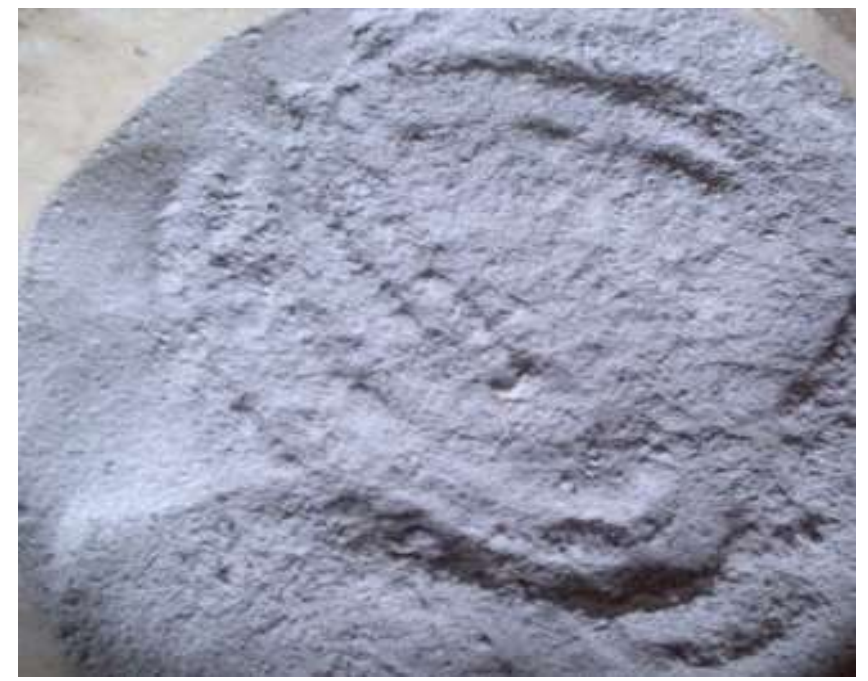

Fig. 3. Corn cob ash

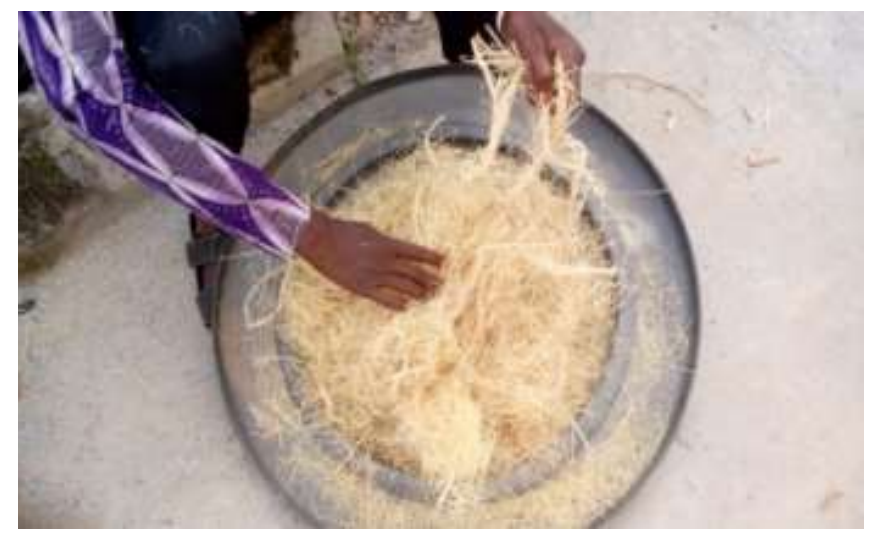

Fig. 4. Kenaf fibre

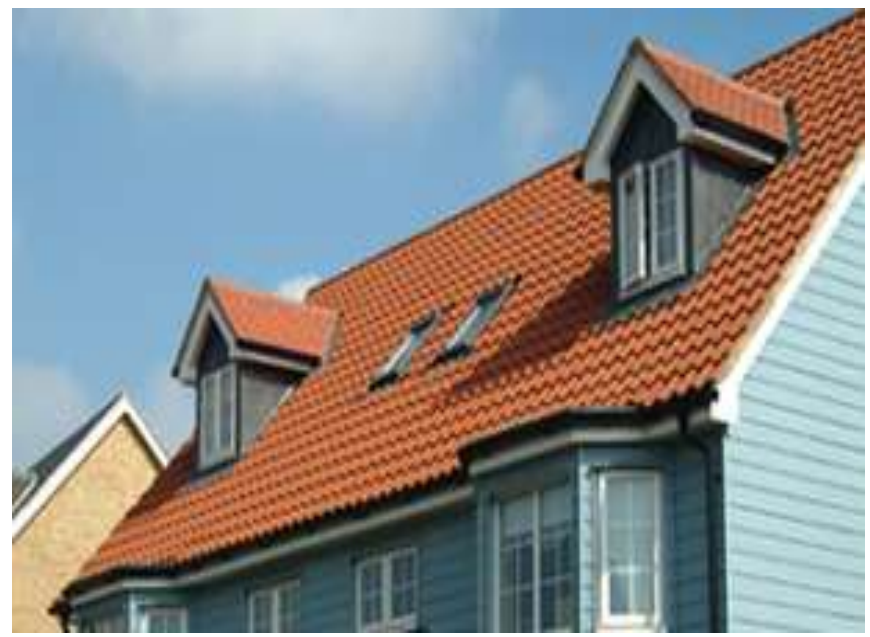

Fig. 5. Finished product Roofing Sheets

Source: www.marleyeternit.co.uk 


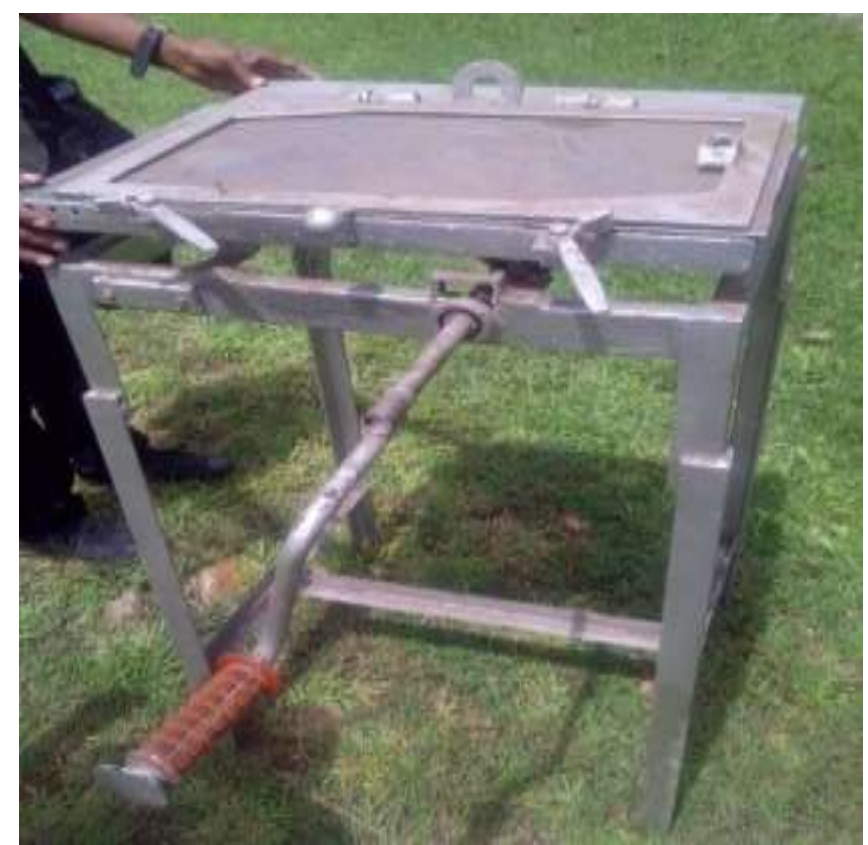

Fig. 6. Vibrator used

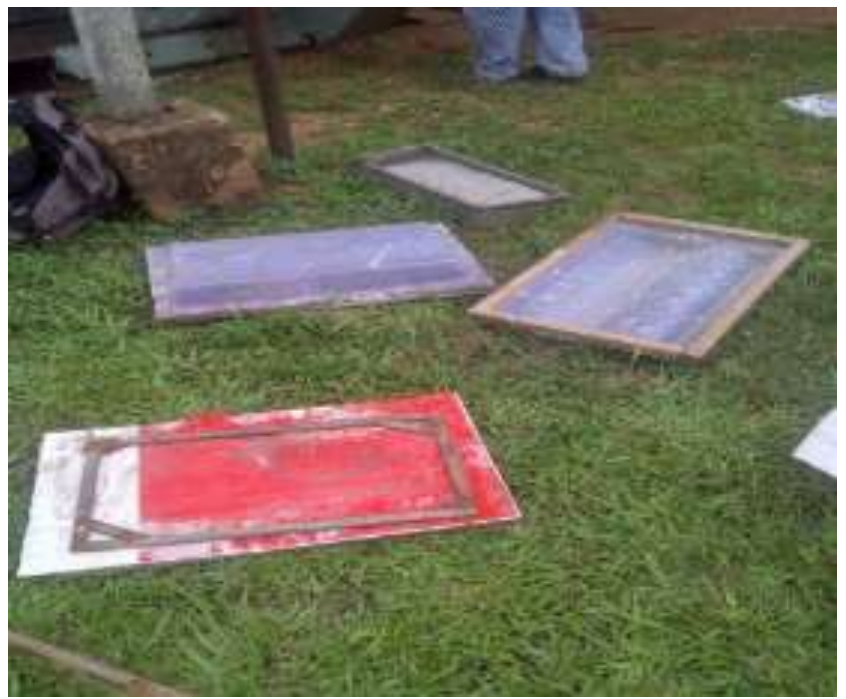

Fig. 7. Moulds and frames used

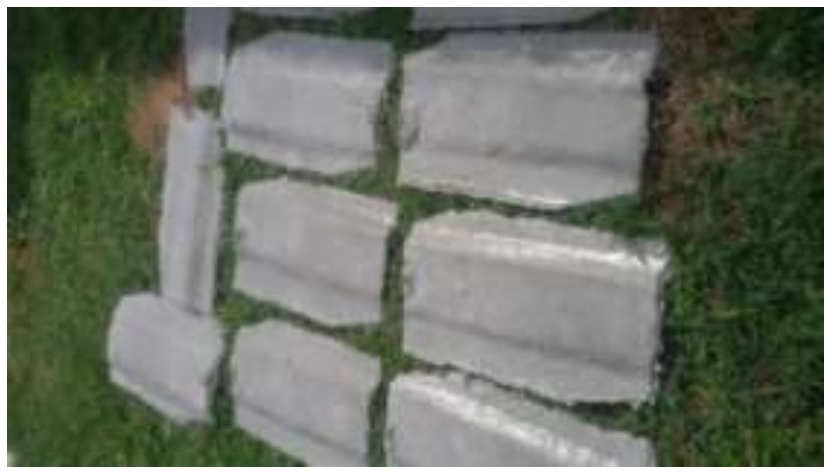

Fig. 8. Air-drying Roof tiles

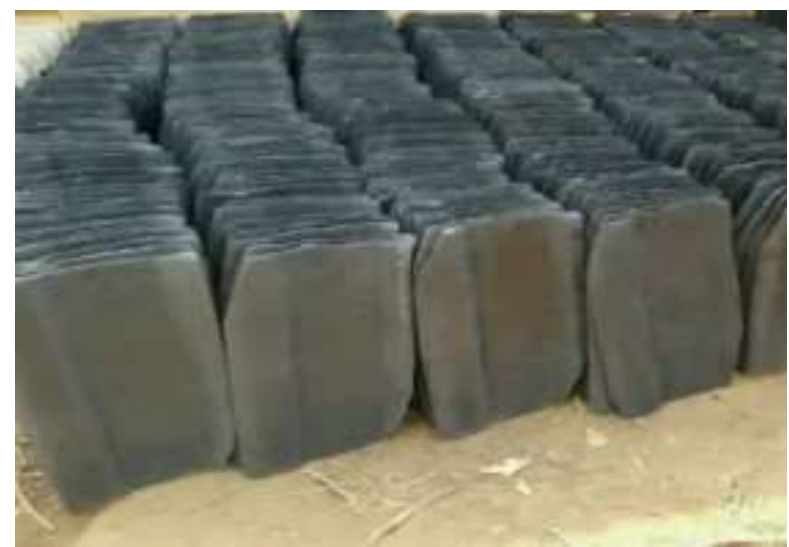

Fig. 9. Stacked roofing sheets

Source: www.bolyncc.com

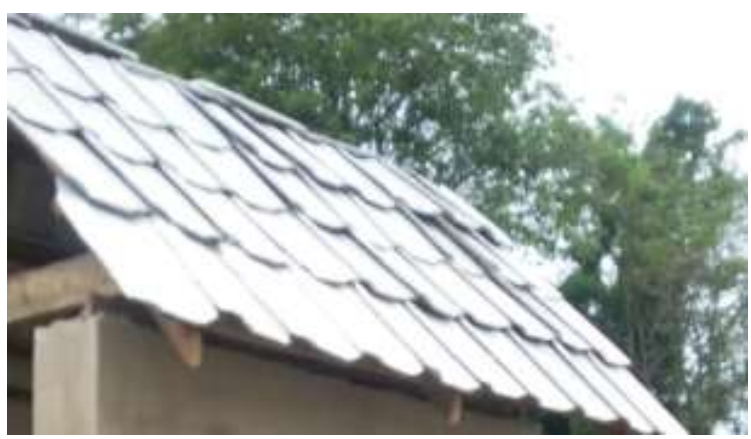

Fig. 10. KF/CCA/Cement Roof tiles demonstration

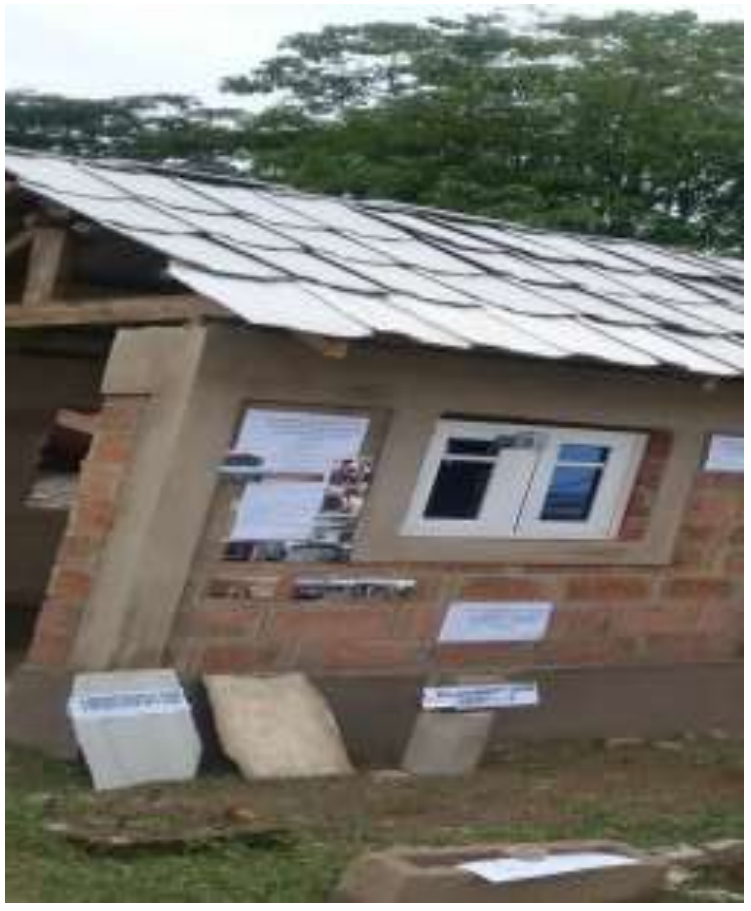

Fig. 11. KF/CCA/Cement Roof tiles Demonstrated with a Brick building 
The experimental work were in two phases, starting with production of cubes for testing, and roofing tiles production as the second phase. The following is the summary of the production process (as shown in the flow chart of Figure 12), of the proposed energy efficient, sustainable, low cost building material. Local manufacturing process using agro-wastes of corn by converting corn cobs to useful material such as ash, a pozzolan, and Kenaf Fibre (KF) which are abundantly available in Nigeria, were employed for the manufacture of roofing tiles for sustainable and indigenous construction.

Corn cob (CC), KF, ordinary Portland cement (OPC) and quarry dust (QD) were locally obtained. The CCA was obtained by air-drying $\mathrm{CC}$, burning in a furnace at $650^{\circ} \mathrm{C}$ and tested for physical and chemical properties using ASTM standards. The KF was sorted to length sizes 15 to $20 \mathrm{~cm}$. The mesh size of QD used was $1.18 \mathrm{~mm}$, classified as fine particles. Batching by weight of KF:(CCA:OPC):QD:(water) was prepared. Samples comprising blended cement of 0.0 (control), 5.0, 10.0, 15.0, 20.0\% CCA and 0.0 (control), 2.5, 5.0, 7.5, 10.0\% of KF using mix ratio 1:3 were produced. Three hundred Cubes $(100 \times 100 \times 100 \mathrm{~mm} 3)$, were cast, de-moulded after 24 hours, cured for 28 days and tested for compressive strength using ASTM C618-12 standards procedure. Specimen measuring $510 \times 300 \times 6 \mathrm{~mm}$ were cast at $7.5 \%$
KF reinforcement in accordance with ASTM standards and were tested for impact strength. A prototype structure (figure 10) using the material as roofing tiles was constructed since 25th October 2015 and monitored till date to ascertain the durability. The colour of CCA was grey and passed through mesh size $0.212 \mu \mathrm{m}$. The silica, alumina and ferric oxide contents of CCA were above $70.0 \%$ indicating pozzolan class $\mathrm{F}$ (fly ash). Highest strengths of the mix were achieved at $5.0 \%$ of CCA and $7.5 \%$ of KF. Compressive strength was $12.42 \pm 0.6 \mathrm{~N} / \mathrm{mm}^{2}$, and impact strength, $85.5 \pm 0.3 \mathrm{KJ} / \mathrm{m}^{2}$ compared with the control $11.0 \pm 0.9 \mathrm{~N} / \mathrm{mm}^{2}$ and impact strength $98.8 \pm 0.3 \mathrm{KJ} / \mathrm{m}^{2}$.

The open air test of prototype structure showed that the material is durable. Jimoh and Apampa compared the energy consumption and the carbon dioxide emission associated with the production of corn cob ash meeting the requirements of ASTM C618-12 (1994) [16], with a view to determining its viability and environmental sustainability as a pozzolan, and they concluded that corn cob ash is a viable and sustainable pozzolan when it is derived from burning process that takes advantage of corn cob as a fuel rather than being specially burnt in a furnace.

This study shows therefore that, the cement composites of corn cob ash and kenaf fibre produced possessed adequate strength and dimensional stability suitable for structural applications such as roof, wall, floor, etc.

TABLE 1

COMPARISON OF ENERGY CONSUMPTION AND $\mathrm{CO}_{2}$ EMISSION DATA, CORN COB ASH VS PORTLAND CEMENT

\begin{tabular}{lll}
\hline Product & Energy consumption $\mathrm{MJ} / \mathrm{KG}$ product & Carbon dioxide emission $\mathrm{KG} / \mathrm{KG}$ product \\
\hline CCA (open air burning) & 4.33 & 0.271 \\
CCA (electric muffle furnace) & 216166 & Not computed \\
Portland Cement & 5.16 & 0.97 \\
\hline
\end{tabular}




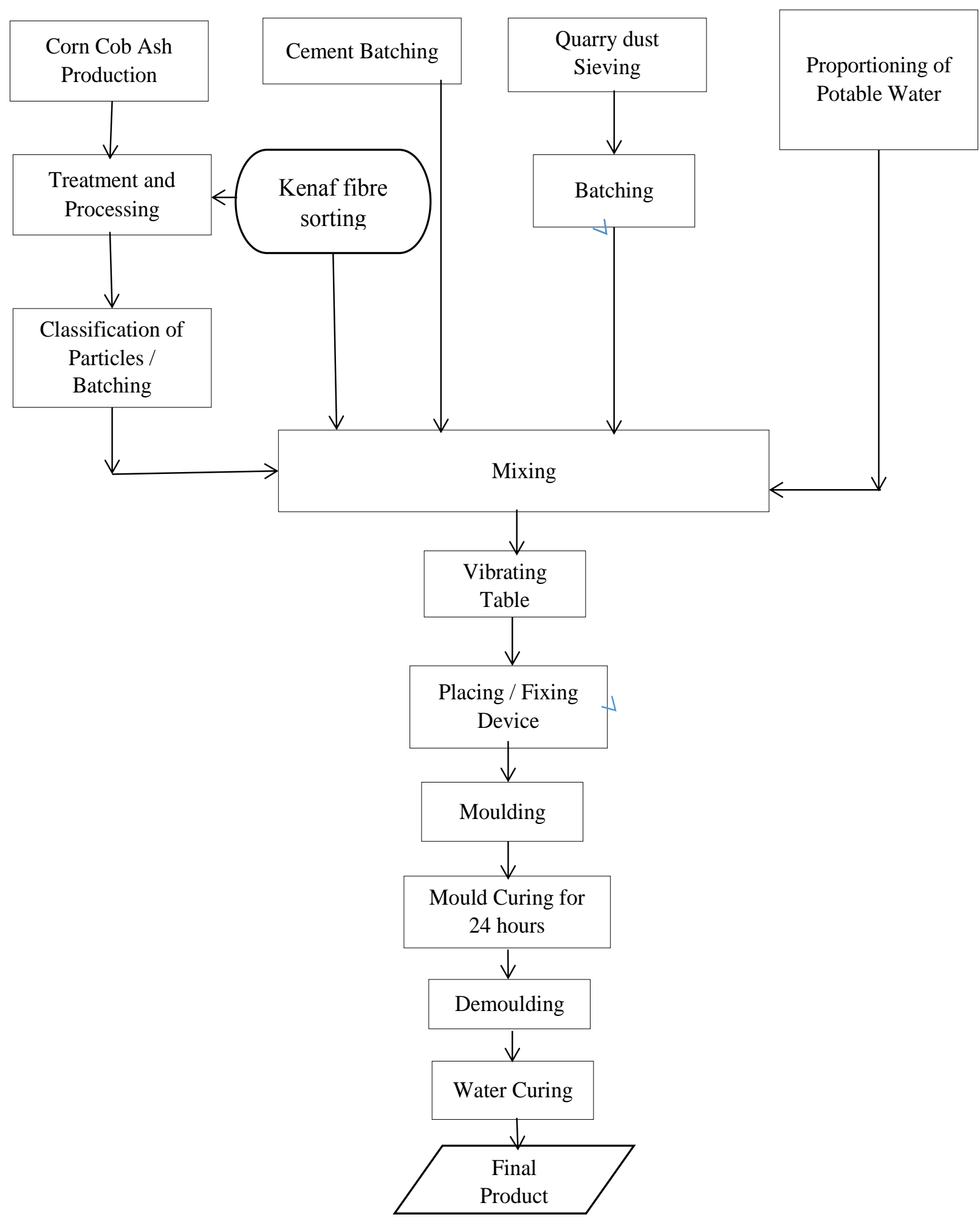

Fig. 12. Flowchart of production process of the composite roofing tiles

\section{A. Compressive Strength Test}

The compressive strength test was evaluated on composite cubes (100 times 100 times $100 \mathrm{~mm}$ ). The steps followed include; (i) curing of cubes, (ii) removal of samples from water, (iii) draining of samples for $20 \pm$
5 minutes, (iv) weighing and (v) crushing. The averageweight-value of three replicate cubes determined was used to evaluate the compressive strength values. 


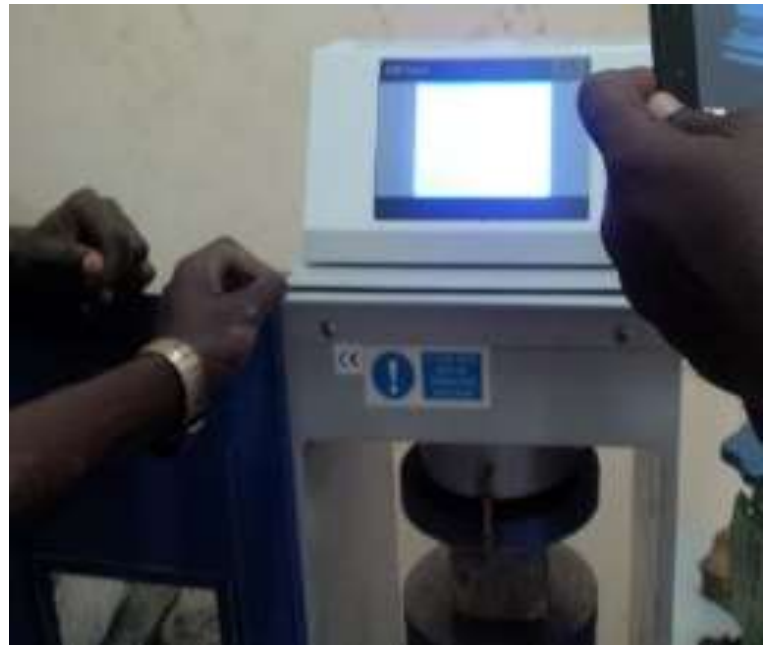

Fig. 13. Compressive strength test of KF/CCA cement composite cubes

The cubes were tested in accordance with British Standard 1881 (1971) [17], using the Avery Denison Universal Testing Machine (Figure 13), by the application of the load cell of the machine at the mid span of the cubes. The various samples were subjected to test including the control in which no CCA was added. The load cell was applied on the samples until the first crack was noticed and the corresponding deflection recorded. The load was subsequently increased at intervals of $2 \mathrm{kN}$ and deflection observed and recorded for each load variation until the final collapse of the sample was attained [18].

\section{RESULTS AND DISCUSSION}

The average compressive strength of the composite cubes produced during this research work for 7 to 28 days strength were from 5.19 to $8.25 \mathrm{~N} / \mathrm{mm} 2,7.68$ to $9.97 \mathrm{~N} /$ $\mathrm{mm}^{2}, 8.56$ to $12.34 \mathrm{~N} / \mathrm{mm}^{2}$ and 4.06 to $7.24 \mathrm{~N} / \mathrm{mm}^{2}$, 4.07 to $7.21 \mathrm{~N} / \mathrm{mm}^{2}$ for $0 \%, 5 \%, 10 \%, 15 \%$ and $20 \%$ ash contents respectively. The maximum value $(12.42 \mathrm{~N} /$ $\mathrm{mm}^{2}$ ) of compressive strength was obtained at $5 \%$ ash contents. While control experiment ( $0 \% \mathrm{CCA}, 0 \% \mathrm{KF})$ has $8.25 \mathrm{~N} / \mathrm{mm}^{2}$ (Figure 14).

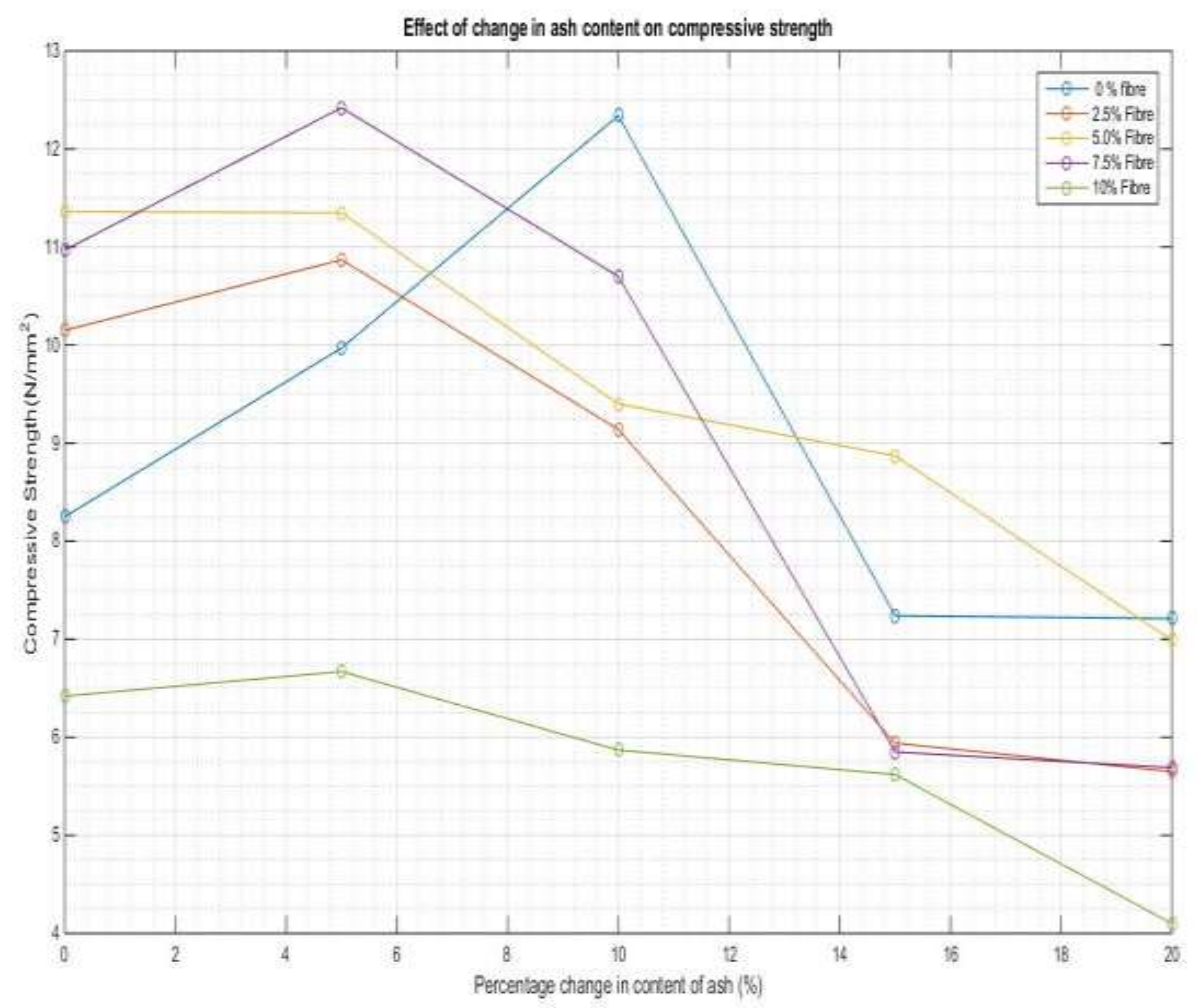

Fig. 14. Average Compressive Strength

Further addition of ash content beyond the optimum level caused reduction in the compressive strength. The reduction in the compressive strength is probably due to the increment in the ash content which tends to cause de-bonding of the matrix. The catastrophic failure was due to the weak interface formed between the binder and the ash contents as the load increased [19], and Omoniyi and Akinyemi also established this fact [17]. The compressive strength of the cubes were observed to increase with an increase in curing age from 7 to 28 curing days as also observed by Zawde Berhane [20], and K Jaiganesh et al [21]. 
TABLE 2

AVERAGE COMPRESSIVE STRENGTH AT 28 DAYS CURING AGE

\begin{tabular}{llll}
\hline Specimen & Fibre $(\%)$ & Ash $(\%)$ & Av. Compressive Strength $\left(\mathrm{N} / \mathrm{mm}^{2}\right)$ at 28 days \\
\hline A(control) & 0 & 0 & 8.25 \\
B & 7.5 & 0 & 10.97 \\
C & 7.5 & 5 & 12.42 \\
D & 7.5 & 10 & 10.70 \\
E & 7.5 & 15 & 5.85 \\
F & 7.5 & 20 & 5.69 \\
\hline
\end{tabular}

\section{LIMITATIONS AND FUTURE RESEARCH}

Energy efficient and low-cost sustainable building materials possess lower strength properties (especially impact strength), and varying quality which is dependent on uncertain influences such as weather and moisture absorption, which causes swelling of the fibres. They could have less durability compared with pure cement composites. They may possess poor fire resistance, their prices can fluctuate considerably by results of harvest or agricultural policies. Future research on laminating, waterproofing, fibre treatments with fire retardants and other treatments can be carried out for improvement. It is worthy of note that the advantages outweighs the limitations and the limitations can be improved upon through future research [13].

\section{CONCLUSION AND RECOMMENDATIONS}

It can be concluded from this study that:

Corn cob ash is a viable and environmentally sustainable source of pozzolan when it is derived from burning processes that take advantage of corn cob as a fuel, rather than being specially burnt in a furnace.

For energy efficiency and sustainability, ensure nearly zero-energy passive building design before actual construction, usage of low energy building materials during its construction, use of energy efficient equipment for low operational energy requirements, integration of renewable energy technologies for various applications.

There is a need for culture change towards greater flexibility in building designs to cater for possible future changes of use or even dismantling and reassembly. The use of relatively simple precast units fixed together in a simple way by mechanical fixing would be a step in this direction. The technique could be applied to structures with timber, steel or concrete frames. It is recognized that this could pose a severe design constraints, and in this respect that a change of attitude to building design would be called for [5].

For the application of such concepts, there is need for increased involvement by governments and professionals.
Also, the circle of discussion and information dissemination needs to be widened so that the information can reach a greater audience.

There should be a strategic alliance between government, construction industry and universities and research centers working together as an effective mechanism to improve the awareness of the topic and to facilitate coordinated action. Global cooperation and relationship can play an important role in influencing governments in developing countries to give adequate and needed recognition to issues related to sustainable building and development [10].

Sustainable vs. Profitable: There is the assumption that environmentally friendly and sustainable practices indicate extra costs. The need to make additional quick profits is very often the excuse not to comply with standards and practices based on principles of sustainability. The building industry complains of a shortage or lack of resources to invest in the technological changes necessary for the application of this concept, and concerned that level of profits will be reduced.

Although an initial cost is needed in order to support the development and production of appropriate technologies and building materials, they are investments that can later be recovered. Besides, these costs can be substantially reduced if the construction sector works together and shares the responsibilities with the government, universities and other private sector related industries and institutions.

Governments are to initiate changes with the development of a working legal framework to encourage the application and enforcement of appropriate standards and procedures. It is known that unless pressured, the construction industry will not put in place the required adjustments in technology. A major factor is to change the way of thinking of both the private and public sector professionals, and the public in general. They need to realize the benefits and advantages of a built environment which is safe to both nature and to the people. The construction sector could use environmentally friendly and sustainable practices as a market strategy to increase the 
popularity and acceptability of their products as in the food industry. As the general public becomes more aware of the benefits that such practices represent for them and the environment, this could consequently have a positive impact in the sales of the proposed products making them sustainable and profitable [10].

\section{Declaratoin of Conflicting Interests}

No competing interests are present in this study.

\section{REFERENCES}

[1] Wikipedia. (2018) Efficient energy use. [Online]. Available: https://bit.ly/1mLRpvI

[2] Total. (2018) Improving energy efficiency. [Online]. Available: https://bit.ly/2IcljJE

[3] British Geological Survey. (2018) Discovering geology. [Online]. Available: https://bit.ly/2F6pveJ

[4] O. Energy. (2018) What is energy efficiency? [Online]. Available: https://bit.ly/2IqUiSg

[5] G. D. Taylor, Materials in construction: principles, practice and performance. London, UK: Pearson Education, 2002.

[6] F. F. Udoeyo, C. I. Anyanwu, R. Brooks, and P. UdoInyang, "Properties of palm nut fiber-reinforced cement composite containing pulverized kernel shell as supplementary material," Journal of Materials in Civil Engineering, vol. 23, no. 4, pp. 378-384, 2011. doi: https://doi.org/10.1061/(asce)mt.1943-5533. 0000178

[7] Z. A. W. Akram W. Ezzat, Ihab A. Wahbi, "Hybrid PCM and transparent solar cells in zero energy buildings," International Journal of Technology and Engineering Studies, vol. 4, no. 2, pp. 102-111, 2018. doi: https://doi.org/10.20469/ijtes.4.10004-3

[8] A. A. Olotuah, A. M. Olotuah, and A. O. Olotuah, "Use of innovative low carbon materials for sustainable energy-efficient housing in Nigeria," WEENTECH Proceedings in Energy, vol. 4, no. 1, pp. 11-15, 2018. doi: https://doi.org/10.32438/wpe. 10718

[9] WCED, "World commission on environment and development," Oxford University Press, Oxford, UK, Tech. Rep., 1987.

[10] L. Miranda and L. Marulanda, "Sustainable construction in developing countries: A Peruvian perspective," in Agenda 21 for Sustainable Construction in Developing Countries, C. du Plessis, Ed. New Delhi, India: CSIR Building and Construction Technology, 2001.

[11] A. Adda, M. Abbas, W. M. Naceur, and Z. Tigrine,
"Contribution on energy consumption optimization of a brackish water solar desalination plant in Algeria," Journal of Advances in Technology and Engineering Studies, vol. 3, no. 2, pp. 37-43, 2017. doi: https://doi.org/10.1016/j.solener.2017.05.021

[12] R. Celly, "Low cost energy efficient and environmental-friendly housing technologies for developing countries," in Sanjaya Lall Memorial Conference on India-Africa Cooperation, Trade and Investment, New Delhi, India, 2007.

[13] O. O. A., "Structural properties and behaviour of corn cob ash and kenaf fibre in cement bonded composites," Department of Civil Engineering, University of Ibadan, Nigeria, Unpublished research report, 2017.

[14] B. H. A. Bakar, R. Putrajaya, and H. Abdulaziz, "Malaysian rice husk ash-Improving the durability and corrosion resistance of concrete: Pre-review," Concrete Research Letters, vol. 1, no. 1, pp. 6-13, 2010.

[15] L. Van Wyk, "Application of natural fibre composites in construction: A research case study," in Sixth International Conference on Composite Science and Technology, ICCST, Durban, South Africa, 2007.

[16] Y. A. Jimoh and O. A. Apampa, "An evaluation of the energy consumption and $\mathrm{co} 2$ emission associated with corn cob ash compared with the cement clinker," Civil and Environmental Research Journal, vol. 3, no. 2, pp. 1-8, 2013.

[17] T. Omoniyi and B. Akinyemi, "Durability based suitability of bagasse cement composite for roofing sheets," Journal of Civil Engineering and Construction Technology, vol. 3, no. 11, pp. 280-290, 2012.

[18] S. Rukzon, P. Chindaprasirt, and R. Mahachai, "Effect of grinding on chemical and physical properties of rice husk ash," International Journal of Minerals, Metallurgy and Materials, vol. 16, no. 2, pp. 242-247, 2009.

[19] L. Van Wyk, "The use of agricultural crops, industrial waste and recycled materials in construction," CSIR, New Dehli, India, CSIR Technical Report, 2005.

[20] Z. Berhane, "Performance of natural fibre reinforced mortar roofing tiles," Materials and Structures, vol. 27, no. 6, pp. 347-352, 1994. doi: https: //doi.org/10.1007/bf02473427

[21] R. P. K. Jaiganesh, S. Dinesh, "A comprehensive review on low cost building systems," International Research Journal of Engineering and Technology, vol. 3, no. 12, pp. 429-433, 2016. 